Research Article

\title{
Lecturers' Competencies: A Qualitatives Study in Higher Education
}

\author{
Samuel P.D. Anantadjaya *, Irma M. Nawangwulan \\ School of International Business Administration, Faculty of Business \& Social Sciences, IULI-International \\ University Liaison, Jl. Masjid Ciater, Serpong, South Tangerang, Banten 15330, Indonesia
}

Article history:

Submission May 2020

Revised August 2020

Accepted August 2020

*Corresponding author:

E-mail: ethan.eryn@gmail.com

\begin{abstract}
The presence of well-known universities outside Indonesia has attracted significant interests, not only from Indonesian residents but also from residents of other countries. Particularly, western universities are highly demanded and the competition is rather fierce when students attempt to register and take on the entrance tests. Only the top percentile of students seems to be accepted. Because of limitations in space and personnel, those western universities decided to expand their market base into developing countries by getting closer to their potential customers. With the technological advancement and push toward the use of the internet and online learning, undoubtedly, international universities, including Indonesian-based universities with mixtures of curricula across countries, have become a new trend in Indonesia's higher educational institutions. With the growing numbers of students applying to international programs at various universities in Indonesia, it is apparent that Indonesians are more assertive to receive internationalized standards. Thus, matching consumer behaviors, and expectations in the local market would be indispensable in trying to ensure the smooth running and operational activities of the international universities in Indonesia. This paper attempts to focus on lecturers/professors, as the pool of human resources/capital in the everlasting competition within the international universities in Indonesia. The focus on lecturers includes issues on human skills, ability in teaching, and teaching delivery, perhaps including research skills and research ability. It is uncertain whether the lecturers' capacity, ability, competence, skills, knowledge, and all attributes of the lecturers to handle international classes are sufficient and fit to the consumer expectations. Research is conducted by gathering data from primary and secondary sources in several locations of international universities in Jakarta, such as lecturers, students, and parents. It is expected that such research would eventually the importance of lecturers' competencies in handling international classes with international standards.
\end{abstract}

Keywords: Lecturer; competence; human capital; international; skills; ability

\section{Introduction}

The presence of well-known universities outside Indonesia has attracted significant interests, not only for Indonesian but also for students of other countries. Particularly, western universities are highly demanded and the competition is rather fierce when students attempt to register and take on the entrance tests. Only the top percentile of students seems to be accepted. Because of limitations in space and personnel, those western universities decided to expand their market base into developing countries, like Indonesia to get closer to their potential customers. Following the economic crisis in Indonesia, the establishments of western universities in Indonesia, including the

How to cite:

Anantadjaya SPD, Nawangwulan IM (2020) Lecturer's competencies: A qualitative study in higher education. Basic and Applied Educational Research Journal 1 (1): 1 - 7. doi: 10.11594/baerj.01.01.01 
joint efforts of promoting international curriculums are flooding the country. In Jakarta and other big cities, especially, the number of international universities are increasing rapidly. Each of those international universities offers different curriculums and specialties, as a way to differentiate themselves among the crowd [1].

People seem to believe that international universities can provide a better quality of education. Thus, to enter the business industry, people tend to send their children to international universities. Perhaps, the perceptions and image of holding international certificates seem to be the key success factor for the public. Besides, it is presumed that people tend to choose international universities due to their advantages, including double-degree programs, overseas internship programs, foreign languages, and better quality of the teaching staff.

Inevitably, the high demand for international courses could be seen as one of many ways to attract students. Different international universities have their strategies in promoting their programs.

This paper attempts to focus on lecturers' competencies, which include issues on human skills, ability to teach, teaching delivery, research skills, and research ability [2,3]. It is expected that by studying lecturers' competencies, the lecturers' abilities to handle classes in international universities are improved, and thus, fit to the consumer expectations.

\section{Education Management}

Education needs proper management. Managing education is, indeed, easier to formulate than to implement those formulations. Regardless of what streams of education management you are trying to follow, lecturers should pay close attention to the outcomes $[4,5]$. Lecturers should be aware that education is a strategic step toward transforming people to grasp more knowledge, skills, and competence [2]. Thus, lecturers should know that they play an important role in molding students for future activities and career paths [6]. One of dimension in proper education management is shown in one of the presentation slides, which accompanied the book "Human Resources Management: Gaining A Competitive Advantage" [7], incorporates an example on job dimensions and tasks of a university professor; teaching, conducting research, advising, performing services, and participating in external consulting works [7] as shown below.

At a glimpse, it appears relatively simple to divide the time in doing all of those 5 different dimensions and tasks. However, as one can easily predict, all of those 5 job dimensions and tasks are not as easy as it seems. Teaching and research tasks are different. Teaching and research tasks require different sets of knowledge, skills, and ability (KSA). Research and service tasks are also different with different sets of KSA, and the comparisons continue among dimensions and tasks.

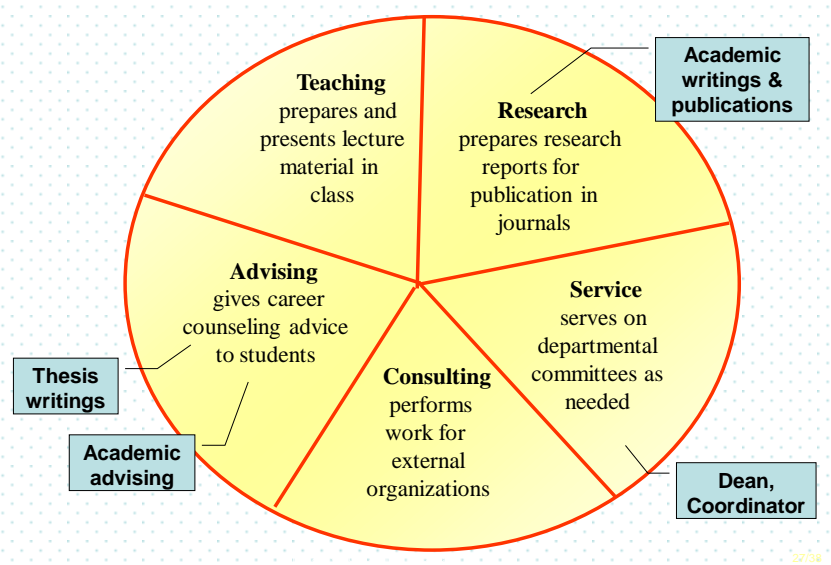

Figure 1. Job dimensions \& tasks of lecturers/professors [7] 
This is not considered exaggerating at all since the business environment is rapidly developed over the last few years, perhaps due to competition. This higher competition level pushes knowledge to advance further. Knowledge is continuously developed to offer better alternatives for making managerial decisions [8] Brainpower seems to control today's business environment more than muscle power [9].

Thus, if brainpower controls the business environment, it means that lecturers ought to update their job dimensions as suggested. If brainpower controls today's business environment, and lecturers are the artists in every class session, then lecturers must equip themselves with the all-around updates; from every single perspective [10], and possibly incorporating as much as current events as possible [11]. In this paper, those perspectives are limited to what Error! Reference source not found. had suggested.

\section{Teaching}

In teaching, it simply means that lecturers should prepare the necessary teaching materials, including homework, assignments, quizzes, and exams on each of the class subjects handled. Lecturers should also ensure that the teaching tools and equipment are available on each of the class sessions. Teaching also means that lecturers should present their materials appropriately for students to understand.

\section{Research}

One of the tasks that lecturers must do is conducting research. Research is intended to prepare reports and findings toward publications in various journals and other academic periodicals. This task is essential to sharpen the analytical and reporting skills of the lecturers. Conducting research is also a way to maintain and continuously improve the knowledge and exposures on various issues. Such knowledge and exposures are excellent to provide the basis on future teaching engagement.

\section{Advising}

Advising is one of the lecturers' responsibilities. Advising sessions is crucial to grasp and/or otherwise update information on each of the students to provide the most suitable research potentials and career path. Advising is important to lecturers, academic services, students, and parents. Through effective advising sessions, lecturers can note potential problems, difficulties, complaints, or suggestions from the students. This information will be relayed into the academic service department for immediate follow-ups. When follow-ups are performed, it is expected that students will be more satisfied. When the students are satisfied, they will likely share wonderful stories about the university to their parents. At the end of the link, it is expected that parents are also pleased with the performance of the university. This minimizes potential complaints to universities. This improves the satisfaction level toward the universities, and the reputation jumps. All this is done by a simple advising session with lecturers.

\section{Services}

This indicates that lecturers are needed to serve as members of a certain committee. This includes holding a certain structural position. Whenever lecturers are holding a particular position, it is somewhat expected that lecturers themselves can initiate necessary actions, including pushing on favorable policies and provisions for the students' best interests.

\section{Consulting}

Engaging in consulting work is highly advisable for lecturers. This is to say that lecturers should actively involve in various consulting projects on behalf of the universities; in terms of business incubator assignments, perhaps, which often focuses on small and medium enterprises. Business incubators are popular in universities, not only for research purposes but also to implement academic knowledge into real situations and conditions in those small and medium enterprises.

\section{Study \& Analysis on Chosen Variables}

The following discussions are based on studies that had been undertaken by ETC \& Foundation in several international universities in Jakarta $[12,13]$. Individual interviews were conducted, including the FGD sessions with selected panels of experts of educational 
practitioners, educational authority, students, parents, and business/industrial practitioners. Such research revealed the following findings:

\section{Teaching}

Teaching is the only activity that lecturers and students have understood properly. However, when the actual activities of teaching are discussed in detail, comments emerged.

\section{Teaching qualities}

Respondents indicated that there are no significant differences in teaching qualities for lecturers in international universities. There are lecturers, who are merely giving lecturers to students, and seem to choose not to engage in additional roles, including acting as facilitators, advisors, and/or counselors. It is expected that lecturers should be able to provide broader views on international perspectives, rather than a mere discussion from the textbooks. Teaching qualities could be improved by industrial knowledge and experience, perhaps. Respondents indicated that lecturers should improve their communication abilities, not only providing conversing in Indonesian but also in English. This appears to be the basic skills on people-approach, as a way to serve the customers of international universities. Respondents also indicated that teaching qualities could be improved substantially by allotting more time to regularly conduct discussions with students on progress and difficulties throughout the semesters. By allotting more time, respondents indicated that lecturers could have a much better knowledge of each student's characteristics, which could be transformed as clues to direct students for future career endeavors. This is particularly true for international universities that offer internship programs, either domestically or internationally. Moreover, this is important to direct students on future research toward the formulation and completion of their theses.

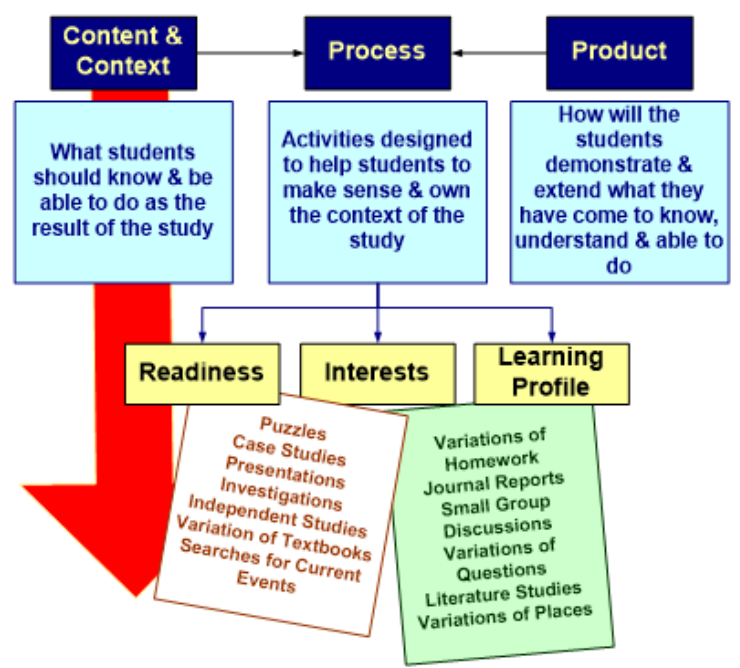

Figure 2. Teaching method $[5,14]$

\section{Teaching styles}

Respondents indicated that lecturers tend to use course plans strictly throughout the semester. As stated earlier, the most common teaching style used is lecturing. Lecturing styles are widely used, not only in class meetings but also to various arrangements of oncampus seminars and workshops. Although questions are frequently allowed, interactive discussions appear to be minimal. Discussions tend to lead to debates with significant emotional involvement. As a result, discussions tend to be avoided. There is also a tendency that lecturers use their academic power over students. It means that lecturers tend to minimize the opportunities for debates; simply because lecturers believe that they have more knowledge. Whenever students try to express their opinions, lecturers tend to have the precondition stage that their opinions are wrong. 
Lecturers seem to have minimal concerns on whether students can understand the study materials. Homework appears to be the number one favorite for teachers without sufficient time spent to really discuss and solve the problems together in class. The authoritarian style appears to be the lecturers' best approach in class management.

\section{Research}

Initially, this is an area, which some respondents may not have a clear understanding of what research is all about. Upon further exclusive discussions in a few focus groups, nonetheless, research seemed to materialize as the foundation toward better teaching. Lecturers who do not spend time in reading newspapers and/or magazines regularly, for example, would likely to lack knowledge on current events, which potentially provide clues for future actions, and teaching directions.

The number one impediment in research is, indeed, the support from the institutions. Support toward conducting research is not readily available as lecturers would have expected. In one international university in our study, research is very minimally supported although the institution has been in providing educational services to students for a couple of years. The minimal supports toward research are also not fairly distributed across different faculties. Though universities are seen as think tanks, not all universities' personnel agree and/or otherwise support the research proposals from lecturers.

The number two impediment in research is the availability of time to do so. Respondents indicated that though institutions support research and continuing education, lecturers may not able to do much if they are heavily burdened with teaching schedules, various tasks, and responsibilities.

This is particularly true for those lecturers, who hold structural positions in many institutions. This finding is, in fact, contradictory with other job dimensions that ought to be performed by lecturers. Respondents indicated that due to the nature of the universities, lecturers in international universities should conduct research more often than those in local universities. This is to provide adequate cushions for the international status of the universities.

\section{Advising}

Respondents indicated that as much as possible, they did not want to participate in advising. They believe that advising is the job for counselors in academic services. Lecturers are only supposed to be responsible for lecturing and delivery of teaching materials following the class syllabus. However, lecturers are expected to have time outside class for questions and tutorials. Just like research, this seems to create a dilemma. As the number of students rises, the advising time increases.

This reduces the available time for lecturers to prepare for teaching materials, research, serving as members of the committee, and participate in consulting work. As international universities are gaining their popularity, the number of students is skyrocketing. To catchup with the growing numbers of students registering at a certain international university, the numbers of lecturers should be added. Failure to do so seems to lead to questions toward lecturers' competencies. Thus, institutional reputation is also questioned.

\section{Services}

Respondents indicated that lecturers should not be assigned certain positions. Structural positions should be held by non-lecturers. There are tendencies that lecturers, who hold structural positions, are more committed to the responsibilities they have structurally. Regular meetings take up substantial times from the lecturers to do some other activities. This is not mentioning the administrative loads that must be taken care of due to their structural positions. Respondents indicated that they were a bit troubled by the fact that many lecturers are busy with their structural agendas than committing more time to students.

\section{Consulting}

Though the majority of respondents agreed that lecturers should participate in consulting work as a way to apply their academic knowledge, lecturers should not forget or oth- 
erwise change their priority. Respondents indicated that the challenge in consulting work is only time management; in which area those lecturers are supposed to be the expert. However, as consulting works tend to take up substantial time, lecturers would only have minimal time in putting their efforts into the academic progress of the students.

\section{Lecturer's performance}

It is rather obvious that lecturers' performance is mainly evaluated by superiors. Though students' comments are sought, their comments are not highly regarded and treated as a mere formality. Respondents indicate that this method of evaluation is rather misleading. Since students know well about how those lecturers managing their classes, the weight on students' comments should be heavier. Nonetheless, students' comments on various evaluation questions do not seem to be fairly weighted toward the overall performance of lecturers. Respondents indicate that many lecturers, both full-time and part-time, tend to be evaluated more on their academic degrees and their contribution to the academic world, such as professorships and research, rather than their competence in handling and delivering materials in class. It is said to say that international universities are not yet fully adopting the best practice in performance evaluations on lecturers to indicate the lecturers' competence [15].

\section{Conclusion}

Based on the study in international universities in Jakarta, there is a wide gap between what students expect to gain and lecturers' competence in meeting those expectations in international universities. Lecturers' competencies in international universities need to be improved, undoubtedly. International universities have to realize such needs for improvement on lecturers' competencies as a way to better-equipped students for the actual working environment upon graduation. Such improvements are necessary to push the international status of the universities. International universities are different from regular/local universities. Thus, lecturers' competencies in handling international classes should not be marginally different from their local counterparts. However, there are strings attached to any changes. The hurdles lie in the hands of the management officers and lecturers themselves in international universities. The willingness and ability to change for those management officers and lecturers remain questionable.

As international universities strive to attract students, one aspect of improving competitiveness is the lecturers' competencies. International universities shall concentrate on advancing their brainpower to excel and come up on top of the competitions.

\section{Acknowledgment}

The authors say thanks to school of International Business Administration Faculty of Business \& Social Sciences IULI-International University Liaison Indonesia for supporting this research.

\section{References}

1. Anantadjaya SP (2011) Community-university partnership in university internship programs in Indonesia: What can we learn from universities with international curricula?. Metropolitan Universities Journal 22(2): 121-130.

2. Anantadjaya SP (2008a) Comparative literature study on the resource-based theory of the firm and knowledge-based theory of the firm. Jurnal Sistem Informasi, Universitas Kristen Maranatha 3(1): 55-73.

3. Anantadjaya SP, Nawangwulan IM (2007) Early child education: profitable innovation? The 2nd Indonesian Business Management Conference. Jakarta, Prasetiya Mulya Business School. pp 1-12.

4. Triana Y (2005) Seni mendidik dalam pendidikan. Wawasan Tridharma XVII(9): 24-26.

5. Anantadjaya SP (2008b) Does higher education teaching need improvement? The Jakarta Post 25(267): 28. Retrieved May 7, 2020, from http://www.thejakartapost.com/detailsupplement.asp?filei $\mathrm{d}=20070909$. (20\&irec $=6$

6. Danumihardja M (2004) Pendidikan sebagai alat pengembangan sumber daya manusia. Wawasan Tridharma XVII(3): 12-15.

7. Noe RA, Hollenbeck JR, Gerhart B, Wright PM (2014). Human resources management: Gaining a competitive advantage (9th ed.). New York City, NY, USA, McGraw-Hill Education.

8. Anatan L (2006) Manajemen modal intelektual: Strategi memaksimalkan nilai modal intelektual dalam teknologydriven business. Jurnal Manajemen 5(2): 137-149.

9. Sangkala (2006) Intellectual capital management: Strategi baru membangun daya saing perusahaan. Jakarta, Penerbit Yapensi.

10. Rachmayati F (2006) Performance appraisal $360^{\circ}$ feedback: Sebuah pendekatan untuk menciptakan competitive advantage bagi organisasi. Jurnal Manajemen 5(2): 95-107.

11. Hopkins G (2016) Why teach current events? (Educational World) Retrieved May 1, 2020, from Home/Professional Development:

https://www.educationworld.com/a_curr/curr084.shtml 
12. ETC \& Foundation (2005) Field study on universities. Internal Report (Anantadjaya Ed. SP, Nawangwulan IM, Trans, Yogaswara SP, Compiler, Jakarta, ETC \& Foundation.

13. ETC \& Foundation (2006) Market Studies in Bandung \& Jakarta. Internal Report Internal Report (Anantadjaya Ed. SP, Nawangwulan IM, Trans, Yogaswara SP, Compiler, Jakarta, ETC \& Foundation.

14. Tomlinson CA (1999) The differentiated classroom: Responding to the needs of all learners. Virginia, USA, Association for Supervision and Curriculum Development.

15. Anantadjaya SP (2009) Measuring human resources: A case study in small and medium enterprises. Seminar Nasional Industrial Services. Cilegon, Banten, Indonesia, Jurusan Teknik Industri, Universitas Sultan Ageng Tirtayasa. pp III.101-119. 